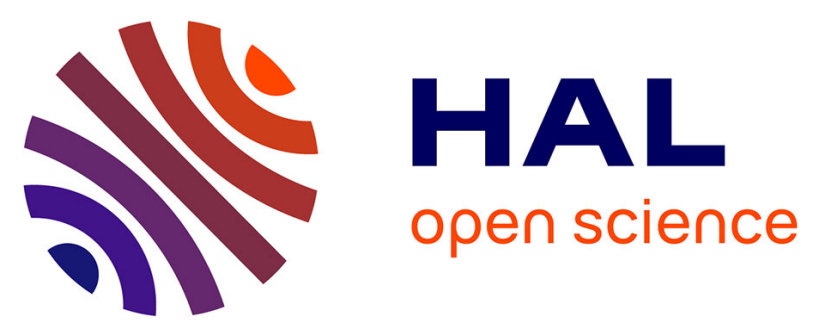

\title{
Effects of [d-Ala6, Pro9-NEt]-LHRH and catecholaminergic drugs on gonadotropin secretion and ovulation in the Chinese loach (Paramisgurnus dabryanus)
}

Hao-Ren Lin, Chun Peng, Glen van Der Karaak, Richard E. Peter, Bernard Breton

\section{To cite this version:}

Hao-Ren Lin, Chun Peng, Glen van Der Karaak, Richard E. Peter, Bernard Breton. Effects of [dAla6, Pro9-NEt]-LHRH and catecholaminergic drugs on gonadotropin secretion and ovulation in the Chinese loach (Paramisgurnus dabryanus). General and Comparative Endocrinology, 1986, 64 (3), pp.389-395. 10.1016/0016-6480(86)90073-0 . hal-01608551

\section{HAL Id: hal-01608551 \\ https://hal.science/hal-01608551}

Submitted on 2 Jun 2020

HAL is a multi-disciplinary open access archive for the deposit and dissemination of scientific research documents, whether they are published or not. The documents may come from teaching and research institutions in France or abroad, or from public or private research centers.
L'archive ouverte pluridisciplinaire HAL, est destinée au dépôt et à la diffusion de documents scientifiques de niveau recherche, publiés ou non, émanant des établissements d'enseignement et de recherche français ou étrangers, des laboratoires publics ou privés.

\section{다(1) (2)}

Distributed under a Creative Commons Attribution - ShareAlikel 4.0 International 


\title{
Effects of [D-Ala ${ }^{6}$, Pro $\left.{ }^{9}-\mathrm{NEt}\right]-\mathrm{LHRH}$ and Catecholaminergic Drugs on Gonadotropin Secretion and Ovulation in the Chinese Loach (Paramisgurnus dabryanus)
}

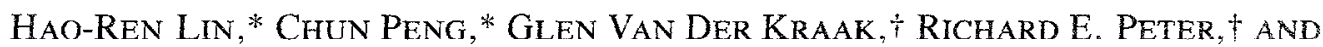 \\ BERNARD BRETON $\ddagger$
}

*Department of Biology, Zhongshan University, Guangzhou, People's Repuhlir of China, tDepatment of Zoology, University of Alberta, Edmonton, Alberta, Canada T6G 2E9, and $t$ Laboratorie de Physiologie des Poissons, Institut Nationale de la Recherche Agronomique, Campus de Beaulieu, 35042 Rennes. France

Accepted July 6, 1986

\begin{abstract}
The effects of $\left[\mathrm{D}-\mathrm{Ala}^{6}, \mathrm{Pro}^{9}-\mathrm{NEt}\right]-\mathrm{LHRH}(\mathrm{LHRH}-\mathrm{A})$ alone and in combination with drugs which influence the actions of dopamine or the synthesis of catecholamines on gonadotropin $(\mathrm{GtH})$ secretion and ovulation in the loach (Paramisgumus dabryanus) were invesígated. LHRH-A alone stimulated an increase in serum GtH levels in the loach, but was a relatively ineffective treatment for the induction of ovulation. Injection of the dopamine receptor antagonist pimozide caused a marked potentiation of the GtH-release response to LHRH-A, and combined injections of pimozide and LHRH-A were an effective treatment for the induction of ovulation. Reserpine, a drug which causes depietion of catecholamines from presynaptic terminals, also caused a marked potentiation of the GtH-release response to LHRH-A and combined treatment induced ovulation. Similarly, administration of $\alpha$ methyl-para-tyrosine to block conversion of tyrosine to L-dopa, or carbidopa to block conversion of L-dopa to dopamine, potentiated the GtH-release response to LHRH-A and induced ovulation. In contrast, the use of diethyldithiocarbamate, to block conversion of dopamine to norepinephrine, failed to augment the action of LHRH-A on GtH release and ovulation. The present results provide further evidence to suggest that dopamine functions as a gonadotropin release-inhibitory factor in teleosts, and demonstrate that the use of drugs which block either the synthesis or the actions of dopamine potentiates the action of LHRH-A in teleosts. 1986 Academic Press. Ine.
\end{abstract}

Recent studies have demonstrated that gonadotropin $(\mathrm{GtH})$ secretion in teleosts is regulated by the stimulatory effects of a gonadotropin-releasing hormone $(\mathrm{GnRH})$ and the inhibitory effects of a gonadotropin release-inhibitory factor (GRIF; for review see Peter, 1982, 1983; Peter et al., 1986). Dopamine functions as a GRIF in goldfish by acting directly at the level of the pituitary to modulate the actions of GnRI as well as by modulating the spontaneous release of GtH (Chang and Peter, 1983b; Chang et al., 1984). In other studies, injection of pimozide (PIM), a dopamine receptor antagonist, has been shown to potentiate the effects of GnRH analogs, such as [D-Ala ${ }^{6}$, Pro $^{9}$-NEt]-LHRH (LHRH-A) on GtH release in goldfish (Chang and Peter, 1983a; Peter et al., 1985; Sokolowska et al., 1985a, b), common carp (Billard et al., 1983; Lin et al., 1985b, 1986), coho salmon (Van Der Kraak et al., 1986), and bream (Lin et al., 1985b). Furthermore, injection of PIM together with LHRH-A is highly effective in inducing ovulation in goldfish (Chang and Peter 1983a; Sokolowska et al., 1984, 1985a) common carp (Billard et al., 1983; Lin et al., 1985b, 1986), Chinese loach (Lin et al., 1985a), African catfish (de Leeuw et al., 1985), and bream and silver carp (Lin et al., 1985b). If dopamine acts as a GRIF, then drugs which block the synthesis of dopamine or cause depletion of dopamine 
from presynaptic terminals should also influence the response to LHRH-A. To test this hypothesis, we have investigated the effects of LHRH-A in combination with drugs which block the synthesis of catecholamines or cause depletion of catecholamines from presynaptic terminals on $\mathrm{GtH}$ secretion and ovulation in the Chinese loach.

\section{MATERIALS AND METHODS}

Loach, 20 to $40 \mathrm{~g}$ body wt, were obtained from a local supplier (Guangdong Province, China) during the spawning season (November-April). Fish were held indoors in 250 -liter aquaria at $20-22^{\circ}$, or outdoors at ambient temperature without vegetation. Sexually mature (preovulatory) females were selected for experiments on the basis of a soft and distended abdomen. Individual fish were identified by means of a fin clip and weighed 1-2 days prior to hormone or drug treatment.

LHRH-A was purchased from the Ningbo Fish Hormone Factory, Zhejiang Province, China. PIM was a gift from Janssen Pharmaceutics Ltd., Beerse, Belgium. Reserpine (RES), $\alpha$-methyl-para-tyrosine $(\alpha-\mathrm{MPT})$, carbidopa (CBD), and diethyldithiocarbamate (DDC) were purchased from Sigma, St. Louis. Missouri. LHRH-A was dissolved in freshwater teleost physiological saline (PS; Burnstock, 1958); drugs were suspended or dissolved in a vehicle (Veh) of $0.7 \% \mathrm{NaCl}$ with $0.1 \%$ sodium metabisulfite. The dosages of LHRH-A and drugs utilized, in micrograms per gram body weight, and the injection schedules are provided under Results. Control groups received PS and/or Veh. All injections were intramuscular near the base of the dorsal fin; injection volumes were $5 \mu \mathrm{l} / \mathrm{g}$ body wt. Blood was sampled at 8 and $24 \mathrm{hr}$ after injection by puncturing the caudal vasculature with a 25 -gauge 0.5 -in. needle attached to a 1.0 -ml disposable syringe. Fish were checked for ovulation $24 \mathrm{hr}$ after injection by abdominal massage, and then killed by spinal transection to determine gonadal condition by visual ovservation. Blood samples were allowed to clot on ice for several hours, and the serum was separated by centrifugation and stored at $-25^{\circ}$.

Serum GtH levels were determined by radioimmunoassay (RIA) using an antiserum directed against the $\beta$ subunit of carp $\mathrm{GtH}$ and carp GtH for the assay standards and tracer. The assay protocol followed that previously described by Peter et al. (1984) except for the use of the carp GtH $\beta$-subunit antiserum at a final dilution of $1: 1,000.000$. Serial dilutions of loach serum and pituitary extract resulted in binding inhibition curves parallel to the carp GtH standard (data not shown). Interassay variation was determined by re- peat measurement of two pools of loach serum with low and high GtH content. Intraassay variation in the measurement of the low serum GtH pool was $7.3 \%(\mathrm{~N}$ $=12$ ) measured at about $80 \%$ of maximal binding and in the high serum $\mathrm{GtH}$ pool was $4.9 \%(N=12)$ measured at about $20 \%$ of maximal binding. Interassay variation was $14.8 \%(N=10)$ and $12.7 \%(N=10)$ for the low and high GtH content serum pools, respectively.

GtH data were analyzed by one-way analysis of variance and Duncan's multiple range test following $\log _{10}$ transformation. Fisher's exact probability test was used to compare the number of ovulated fish between groups $(P<0.05)$.

\section{RESULTS}

Injection of LHRH-A alone at 0.01 or $0.05 \mu \mathrm{g} / \mathrm{g}$ body wt was effective in stimulating an increase in serum GtH levels in the loach (Figs. 1-6). However, the rate of ovulation induced by LHRH-A alone was generally low, usually at about $25 \%$ of the test animals but ranging up to $40 \%$.

As shown in Fig. 1, combined injections of PIM + LHRH-A and RES + LHRH-A resulted in higher serum $\mathrm{GtH}$ levels than injections of LHRH-A + VEH at $8 \mathrm{hr}$ post-

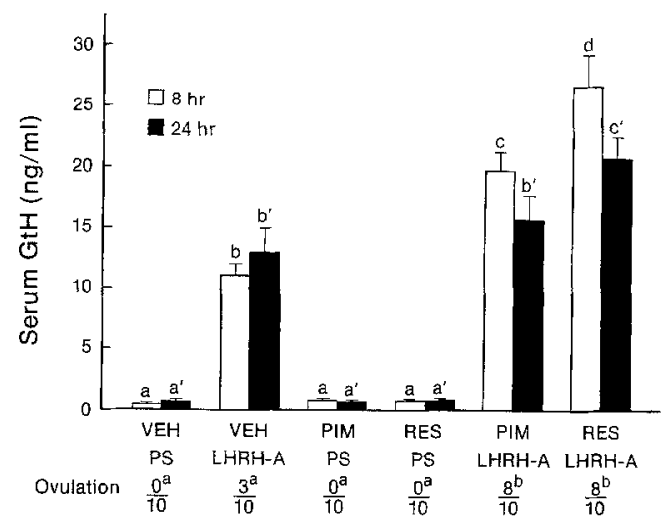

FrG. 1. Effects of PLM ( $5 \mu \mathrm{g} / \mathrm{g}$ body weight) or Res ( $5 \mu \mathrm{g} / \mathrm{g}$ body $w \mathrm{t}$ ) alone and in combination with LHRH-A $(0.05 \mu \mathrm{g} / \mathrm{g}$ body wt) on serum GtH levels and ovulation in loach. Gonadotropin values are reported as means \pm SE. At each sampling time, groups with similar serum $\mathrm{GtH}$ levels, as determined by Duncan's Multiple Range Test $(P>0.05)$, are identified by the same superscript. Groups with similar rates of ovulation as determined by Fisher's Exact Probability Test $(P>0.05)$ are also identified by the same superscript. 
injection; the magnitude of the increase was greatest in RES + LHRH-A injected fish. At $24 \mathrm{hr}$, serum GtH levels in PIM + LHRH-A injected fish were similar to LHRH-A + VEH injected fish; however, the serum GtH levels in RES + LHRH-A injected fish remained significantly elevated. Injections of PIM + PS or RES + PS failed to stimulate an increase in serum $\mathrm{GtH}$ levels at 8 or $24 \mathrm{hr}$ after injection when compared to the $\mathrm{VEH}+\mathrm{PS}$ injected group. The ovulatory response to injections of PIM alone, RES alone, or LHRHA did not differ from control fish; the combination of PIM or RES + LHRH-A resulted in a significant ovulatory response $(80 \% ; 8 / 10)$.

The effects of graded amounts of RES administered together with LHRH-A (0.05 $\mu \mathrm{g} / \mathrm{g}$ body wt) on serum GtH levels and ovulation are shown in Fig. 2. Injections of RES alone at dosages of 0.5 or $5 \mu \mathrm{g} / \mathrm{g}$ body wt stimulated a modest but significant increase in serum GtH levels at 8 and $24 \mathrm{hr}$ postinjection when compared to $\mathrm{VEH}+$ PS injected fish; injection of a low dosage of RES alone $(0.05 \mu \mathrm{g} / \mathrm{g}$ body wt) was ineffective. Administration of RES alone failed to induce ovulation. Injection of RES $(0.5$ or $5 \mu \mathrm{g} / \mathrm{g}$ body wt) together with LHRH-A stimulated a significant increase in serum $\mathrm{GtH}$ levels at $8 \mathrm{hr}$ postinjection compared

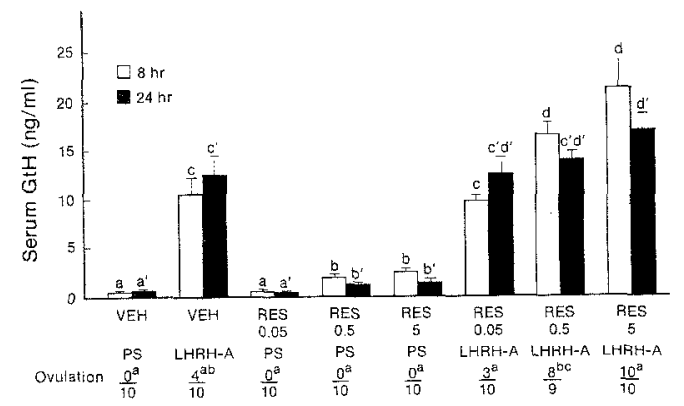

FIG. 2. Effects of graded dosages of $\operatorname{RES}(0.05,0.5$, and $5 \mu \mathrm{g} / \mathrm{g}$ body $\mathrm{wt}$ ) alone and in combination with LHRH-A $(0.05 \mu \mathrm{g} / \mathrm{g}$ body wt) on serum $\mathrm{GtH}$ levels and ovulation in loach. See caption to Fig. 1 for details of the legend. to VEH + LHRH-A injected fish. At $24 \mathrm{hr}$, only fish receiving the high dose of RES (5 $\mu \mathrm{g} / \mathrm{g}$ body wt) + LHRH-A maintained elevated serum GtH levels comparcd to VEH + LHRH-A injected fish. Serum GtH levels in fish receiving a low dose of RES $(0.05 \mu \mathrm{g} / \mathrm{g}$ body wt $)+$ LHRH-A did not differ from the levels found in fish receiving LHRH-A alone at either 8 or $24 \mathrm{hr}$. Combined injections of RES $(0.5$ and $5 \mu \mathrm{g} / \mathrm{g}$ body wt) + LHRH-A resulted in a significant increase in the number of fish which ovulated compared to treatment with either I.HRH-A alone or LHRH-A and a low dose of RES $(0.05 \mu \mathrm{g} / \mathrm{g}$ body $w \mathrm{t})$.

The effects of RES $(5 \mu \mathrm{g} / \mathrm{g}$ body wt) and $\alpha$-MPT (50 $\mathrm{mg} / \mathrm{g}$ body wt) alone and in combination with LHRH-A $(0.05 \mu \mathrm{g} / \mathrm{g}$ body wt) on serum GtH levels and ovulation in the loach are shown in Fig. 3. Although RES alone stimulated an increase in serum GtII levels at 8 and $24 \mathrm{hr}$ postinjection and $\alpha$-MPT alone increased serum $\mathrm{GtH}$ levels at $8 \mathrm{hr}$ postinjection compared to $\mathrm{VEH}+\mathrm{PS}$ injected fish, these treatments were ineffective in inducing a high rate of ovulation. Administration of RES + LHRH-A or $\alpha$-MPT + LHRH-A resulted in significantly higher serum GtH levels at

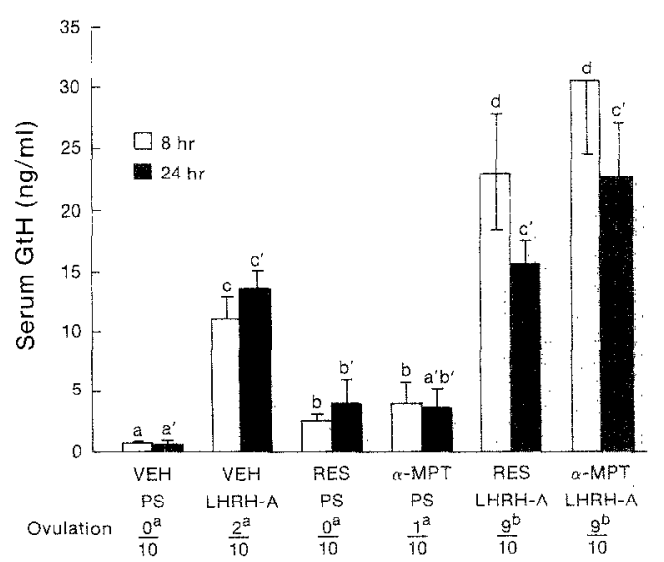

FIG. 3. Effects of RES ( $5 \mu \mathrm{g} / \mathrm{g}$ body wt) or $\alpha-M P T$ $(50 \mu \mathrm{g} / \mathrm{g}$ body $w \mathrm{t})$ alone and in combination with LHRH-A $(0.05 \mu \mathrm{g} / \mathrm{g}$ body wt) on serum GtH levels and ovulation in loach. See caption to Fig. 1 for details of the legend. 


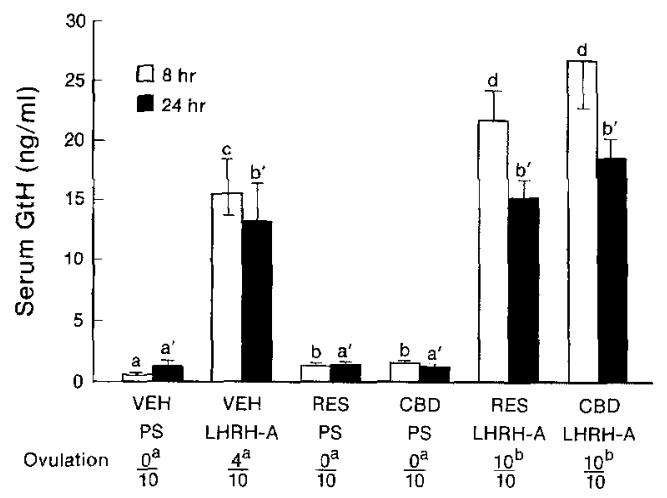

FIG. 4. Effects of RES ( $5 \mu \mathrm{g} / \mathrm{g}$ body wt) or CBD (10 $\mu \mathrm{g} / \mathrm{g}$ body wt) alone and in combination with LHRHA $(0.05 \mu \mathrm{g} / \mathrm{g}$ body wt) on serum $\mathrm{GtH}$ levels and ovulation in loach. See caption to Fig. 1 for details of the legend.

$8 \mathrm{hr}$ compared to fish receiving LHRH-A alone. Serum GtH levels were similar at 24 $\mathrm{hr}$ postinjection in groups receiving LHRH-A alone or in combination with RES or $\alpha$-MPT. Both RES and $\alpha$-MPT in combination with LHRH-A resulted in a significant increase in the rate of ovulation compared to treatment with LHRH-A alone.

The effects of RES ( $5 \mu \mathrm{g} / \mathrm{g}$ body wt) and CBD $(10 \mu \mathrm{g} / \mathrm{g}$ body wt) alone and in combination with LHRH-A $(0.05 \mu \mathrm{g} / \mathrm{g}$ body wt) on serum GtH levels and ovulation in the loach are shown in Fig. 4. Both RES alone and $\mathrm{CBD}$ alone stimulated a small but significant increase in serum GtH levels compared to VEH + PS treated fish at $8 \mathrm{hr}$, but not at $24 \mathrm{hr}$; these treatments were ineffective in inducing ovulation. Administration of RES + LHRH-A or CBD + LHRH-A resulted in significantly higher serum $\mathrm{GtH}$ levels at 8 hr compared to fish receiving LHRH-A alone. Serum GtH levels were similar at $24 \mathrm{hr}$ postinjection in groups receiving LHRH-A alone or in combination with RES or CBD. Combined treatments of RES + LHRH-A and CBD + LIHRH-A resulted in a significant increase in the number of fish which ovulated compared to treatment with LHRH-A alone.

The effects of RES ( $5 \mu \mathrm{g} / \mathrm{g}$ body wt) and graded amounts of DDC alone and in combination with LHRH-A ( $0.01 \mu \mathrm{g} / \mathrm{g}$ body wt) on serum GtH levels and ovulation in the loach are shown in Fig. 5. RES alone stimulated a small but significant increase in serum GtH levels at 8 and $24 \mathrm{hr}$ postinjection whereas a high dose of DDC $(50 \mu \mathrm{g} / \mathrm{g}$ body wt) alone was ineffective. Fish receiving the high dose of DDC + LHRH-A had significantly lower serum GtH levels than fish receiving LHRH-A alone at $8 \mathrm{hr}$ but were similar at $24 \mathrm{hr}$ postinjection. Serum GtH levels in fish receiving a lower dose of DDC ( $5 \mu \mathrm{g} / \mathrm{g}$ body $w t)+$ LHRH-A were similar to the levels in fish receiving LHRH-A alone at 8 and $24 \mathrm{hr}$ postinjection. The administration of a high dose of DDC alone as well as low or high doses of DDC + LHRH-A were ineffective in inducing ovulation. In contrast, injection of RES + LHRH-A resulted in significantly higher serum GtH levels at 8 and $24 \mathrm{hr}$ postinjection compared to fish receiving LHRH-A alone, and RES + LHRH-A was highly effective in inducing ovulation.

A final experiment was conducted to compare the effects of a combined injection of LHRH-A $(0.01 \mu \mathrm{g} / \mathrm{g}$ body wt) with PIM, RES, $\alpha$-MPT, or CBD al similar dosages (5 $\mu \mathrm{g} / \mathrm{g}$ body wt) on serum GtH levels and

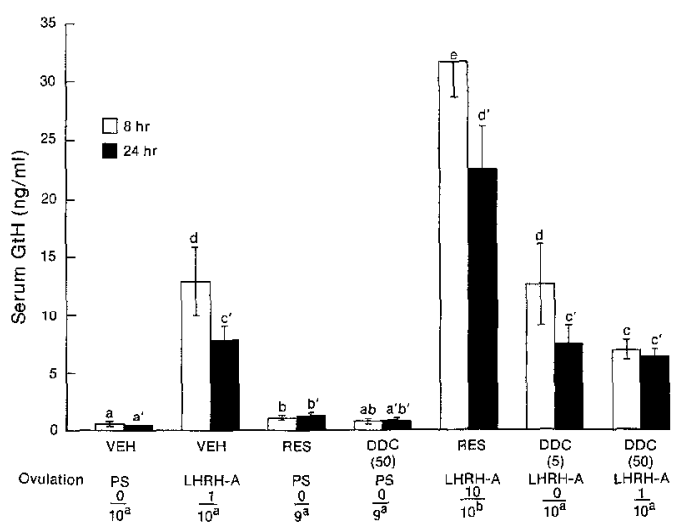

FIG. 5. Effects of RES ( $5 \mu \mathrm{g} / \mathrm{g}$ body wt) or graded amounts of DDC ( 5 and $50 \mu \mathrm{g} / \mathrm{g}$ body $w \mathrm{t}$ ) alone and in combination with LHRH-A (0.01 $\mu \mathrm{g} / \mathrm{g}$ hody wt) on serum GtH levels and ovulation in loach. See caption to Fig. 1 for details of the legend. 
ovulation in the loach (Fig. 6). Each of the drugs administered alone failed to stimulate an increase in serum GtH levels compared to VEH + PS treated fish and were ineffective in inducing ovulation. LHRH-A alone and in combination with CBD had similar effects on serum GtH levels; treatment with LHRH-A in combination with PIM, RES, or $\alpha$-MPT resulted in higher serum GtH levels than injection of LHRHA alone. At 8 and 24 hr, RES + LHRH-A injected fish had higher serum GtH levels than $\alpha$-MPT + LHRH-A treated fish. The ovulatory response of fish injected with $\alpha-\mathrm{MPT}+\mathrm{LHRH}-\mathrm{A}$ or CBD + LHRH-A was similar to fish receiving LHRH-A alone. In contrast, fish treated with PIM + LHRH-A or RES + LHRH-A had a significantly greater ovulatory response than fish receiving $\mathrm{LHRH}-\mathrm{A}$ alone.

\section{DISCUSSION}

The present results demonstrated that LHRH-A stimulates GtH release in sexually mature (preovulatory) Chinese loach; however, treatment with LHRH-A alone was relatively incffective in inducing ovulation. PIM potentiated the GtH-release response to LHRH-A; the combined treatment was highly effective in inducing ovu- lation. This suggests that dopamine has GRIF activity in the loach and confirms the results of our earlier study (Lin et al., 1985a) in which we demonstrated that treatment with PIM and LHRH-A was an effective technique for inducing ovulation in this species.

The actions of RES, $\alpha-M P T, C B D$, and DDC have been well characterized (Gilman et al., 1980). RES causes depletion of catecholamine neurotransmitters by blocking the transport of neurotransmitters into intragranular stores in presynaptic terminals. The drug $\alpha$-MPT blocks the formation of $L$ dopa from tyrosine; CBD blocks conversion of L-dopa to dopamine; DDC blocks conversion of dopamine to norepinephrine. Intraperitoneal injections of RES, $\alpha-M P T$, and $C B D$ caused a significant although relatively small increase in serum $\mathrm{GtH}$ levels in goldfish (Chang et al. 1983). In the present study on Chinese loach, RES, $\alpha$-MPT, and CBD caused a small but significant increase in serum GtH levels, although a consistent response to these drugs could not be demonstrated in each of the experiments.

RES, $\alpha-M P T$, and CBD each potentiated the action of LHRH-A (Figs. 1-6) resulting in significantly higher serum $\mathrm{GtH}$ levels

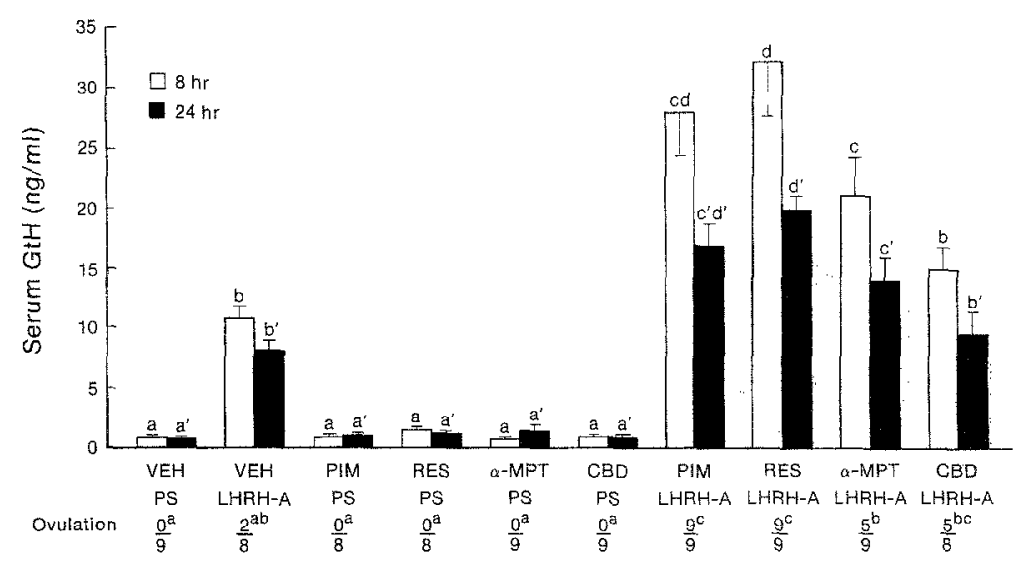

FIG. 6. Effects of PIM, RES, $\alpha$-MPT, and CBD (all dosages $5 \mu \mathrm{g} / \mathrm{g}$ body wt) alone and in combiration with LHRH-A $(0.01 \mathrm{\mu g} / \mathrm{g}$ body wt) on serum GtH levels and ovulation in the loach. See Fig. 1 for details of the legend. 
than in animals treated with LHRH-A alone. However, a high dosage of DDC failed to potentiate the action of LHRH-A in the Chinese loach with DDC $(50 \mu \mathrm{g} / \mathrm{g}$ body wt) + LHRH-A injected fish having lower serum GtH levels at $8 \mathrm{hr}$ postinjection than fish receiving LHRH-A alone (Fig. 5). Taken together, these results indicate that any drug that blocks the synthesis of dopamine, but not the synthesis of norepinephrine, can potentiate the action of injected LHRH-A, presumably by effectively reducing the level of dopamine acting as GRIF on the GtH cells in the pituitary. Based on the present results alone we cannot exclude the possibility that dopamine also influences the activity of $\mathrm{GnRH}$ neurons. However, it would seem that these effects would be of somewhat lesser importance than direct actions on the GtH cells as LHRH-A alone stimulates only a modest increase in $\mathrm{GtH}$ secretion. The present results also confirm a preliminary study showing that RES, 6-hydroxydopamine, $\alpha$-MPT, and CBD, but not DDC, potentiate the $\mathrm{GtH}$ releasing activity of LHRH-A in goldfish (Peter et al., 1986). These studies together lend further support to the idea that GRIF activity is specific to dopamine in goldfish (Chang et al., 1984) and teleosts in general (Peter et al., 1986).

PIM and RES were more effective, on a weight-specific basis, than $\alpha$-MPT or CBD in potentiating the actions of $\mathrm{LHRH}-\mathrm{A}$ on GtH release and ovulation (Fig. 6); however, it is unclear, based on the present results, whether one of the former two (Pim or RES) is more effective than the other. PIM and RES were of equal effectiveness based on the results shown in Fig. 6, although this may reflect the relatively high doses of the two drugs used in this study. The results presented in Fig. 2 demonstrate that the effects of RES are dose dependent, with levels of RES a low as $0.5 \mu \mathrm{g} / \mathrm{g}$ body wt causing a marked potentiation of LHRH-A effects on GtH release and the induction of ovulation. In separate studies,
PIM $(0.5 \mu \mathrm{g} / \mathrm{g}$ body wt) injected together with LHRH-A $(0.05 \mu \mathrm{g} / \mathrm{g}$ body wt) was shown to be effective in inducing ovulation in the loach (Lin et al., 1985a). The effects of RES may be more prolonged than PIM in that the combination of RES + LHRHA maintained elevated serum $\mathrm{GtH}$ levels at $24 \mathrm{hr}$ postinjection whereas the serum $\mathrm{GtH}$ levels in PIM + LHRH-A injected fish were similar to LHRH-A + VEH injected fish (Fig. 1). Other studies on common carp have also demonstrated a more prolonged elevation of serum GtH levels following injection of RES + LHRH-A compared to PIM + LHRH-A (Lin et al. 1986). However, interpretation of differences in the effectiveness of PIM and RES is further complicated by differences in their solubility in the injection vehicle; RES being highly soluble and PIM relatively insoluble in the vehicle used in the present work. Further tests are warranted using an injection vehicle which permits solubilization of both drugs.

In summary, the present results demonstrate that drugs which either cause depletion of catecholamines, or that block catecholamine synthesis at steps up to and including the production of dopamine, potentiate the $\mathrm{GtH}$ releasing action of LHRH-A in the loach; blocking the conversion of dopamine to norepinephrine has no apparent effect on the action of LHRHA. These results confirm the specificity of dopamine as GRIF in the loach.

\section{ACKNOWLEDGMENTS}

This work was supported by Grant 3-P-83-1101 from the International Development Research Centre of Canada to H.-R. Lin and R. E. Peter. G.V.D.K. was supported by a Fellowship from the Alberta Heritage Foundation for Medical Research.

\section{REFERENCES}

Billard, R., Alagarswami, K., Peter, R. E., and Breton, B. (1983). Potentialisation par le pimozide des effets du LHRH-A sur la secretion gonadotrope hypophysaire l'ovulation et la spermia- 
tion chez la carpe commune (Cyrpinus carpio). C.R. Acad. Sci. Paris 296, 181-184.

Burnstock, G. (1958). Saline for fresh-water fish. $J$. Physiol., 141, 35-45.

Chang, J. P., Cook, A. F., and Peter, R. E. (1983). Influence of catecholamines on gonadotropin secretion in goldfish, Carassius auratus, Gen. Comp. Endocrinol. 49, 22-31.

Chang, J. P., and Peter, R. E. (1983a). Effects of pimozide and des-Gly ${ }^{10}\left[\mathrm{D}-\mathrm{Ala}^{6}\right]$ Iuteinizing hormone-releasing hormone ethylamide on serum gonadotropin concentrations, germinal vesicle migration and ovulation in female goldfish, Carassius auratus. Gen. Comp. Endocrinol. 52, $30-31$.

Chang, J. P., and Peter, R. E. (1983b). Effects of dopaminc on gonadotropin relcase in femalc goldfish, Carassius auratus. Neuroendocrinology 36, 351-357.

Chang, J. P., Peter, R. E., Nahorniak, C. S., and Sokolowska, M. (1984). Effects of catecholaminergic agonists and antagonists on serum gonadotropin concentration and ovulation in goldfish: Evidence for specificity of dopamine inhibition of gonadotropin secretion. Gen. Comp. Endocrinol. $55,351-360$.

de Leeuw, R., Resink, J. W., Rooyakkers, E. J. M., and Goos, H. J. TH. (1985). Pimozide modulates the luteinizing hormone-releasing hormone effect on gonadotropin release in the African Catfish, Clarias lazera. Gen. Comp. Endocrinol. 58, 120-127.

Gilman, A. G., Goodman, L. S., and Gilman, A. (1980). "Goodman and Gilman's The Pharmacological Basis of Therapeutics," 6th ed. Macmillan Co., New York.

Lin, H.-R., Liang, J.-Y., Peng, C., Li, G.-Y., Lu, L.-Z., Zhou. S.-J., Chang, M.-L., Van Der Kraak, G., and Peter, R. E. (1986). Pimozide and reserpine potentiate the effects of LHRH-A on gonadotropin secretion and ovulation in cultivated fishes in China. In "Proceedings of the Asian Symposium on Freshwater Fish Culture" (in press).

Lin, H.-R., Peng, C., Lu, L.-Z., Zhou, S.-J., Van Der Kraak, G., and Peter, R. E. (1985a). Induction of ovulation in the loach (Paramisgurnus dabryanus) using pimozide and $\left\lfloor\mathrm{D}-\mathrm{Ala}^{5}\right.$, Pro ${ }^{9}-N$-ethylamide]-LHRH. Aquaculture 46, 330-340.

Lin, H.-R., Van Der Kraak, G., Liang, J.-Y., Peng, C., Li, G.-Y., Lu, L.-Z., Zhou, X.-J., Chang, M.-L., and Peter, R. E. (1985b). The effects of LHRH analogue and drugs which block the effects of dopamine on gonadotropin secretion and ovulation in fish cultured in China. In "Proceedings of the International Symposium on the Aquaculture of Carp and Related Species" (R. Billard, ed.), INRA Publications, Versailles, France (in press).

Peter, R. E. (1982). Nature, localization and actions of neurohormones regulating gonadotropin secretion in teleosts. In "Proceedings of the International Symposium on Reproductive Physiology of Fisin" (H. H. Th. Goos and C. J. J. Richter. eds.), pp. 30-30. Wageningen. The Netherlands, 2-6 August, 1982, Pudoc, Wageningen.

Peter, R. E. (1983). The brain and neurohormones in teleost reproduction. In "Fish Physiology" (W. S. Hoar. D. J. Randall, and E. M. Donaldson, eds.). Vol. IX, Part A, pp. 97-135. Academic Press, New York.

Pcter, R. E., Chang, J. P., Nahorniak, C. S., Omeljaniuk, R. J., Sokolowska, M. Shih, S. H., and Billard. R. (1986). Interactions of catecholamines and GnRH in regulation of gonadotropin secretion in teleost fish. Recent Prog. Horm. Res. 42. 513-548.

Peter, R. E., Nahorniak, C. S., Chang, J. P., and Crim, L. W. (1984). Gonadotropin release from the pars distalis of goldfish, Carassius auratus. transplanted beside the brain or into the brain ventricles: Additional evidence for gonadotropin release-inhibitory factor. Gen. Comp. Endocrinol. $55,337-346$.

Peter, R. E., Nahorniak, C. S., Sokolowska, M., Chang, J. P., Rivier, J. E., Vale, W. W., King J. A., and Millar, R. P. (1985). Structure-activity relationships of mammalian, chicken, and salmon gonadotropin releasing hormones in vivo in goldfish. Gen. Comp. Endocrinol. 58, $231-242$.

Sokolowska. M., Peter, R. E.. and Nahorniak, C. S. (1985a). The effects of different doses of pimozide and $\left[\mathrm{D}-\mathrm{Ala}^{6}, \mathrm{Pro}^{9}-\mathrm{N}\right.$-ethylamide]-LHRH (LHRHA) on gonadotropin release and ovulation in female goldfish. Canad. J. Zool. 63, 1252-1256.

Sokolowska, M., Peter, R. E., Nahorniak, C. S., and Chang, J. P. (1985b). Seasonal effects of pimozide and des-Gly ${ }^{10}\left[\mathrm{D}-\mathrm{Ala}^{6}\right]$-LHRH ethylamide on gonadotropin secretion in goldfish. Gen. Comp. Endocrinol. 57, 472-479.

Sokolowska, M., Peter, R. E., Nahorniak, C. S., Pan, C. H., Chang, J. P., Crim, L. W., and Weil, C. (1984). Induction of ovulation in goldfish, $\mathrm{Ca}$ rassius auratus, by pimozide and analogues of LH-RH. Aquaculture 36, 71-83.

Van Der Kraak, G., Donaldson, E. M., arid Chang, J. P. (1986). Dopamine involvement in the regulation of gonadotropin secretion in coho salmon. Canad. J. Zool. 64, 1245-1248. 